\title{
Abundance of raptors and habitat preferences of the common buzzard Buteo buteo and the common kestrel Falco tinnunculus during the non-breeding season in an agricultural landscape (western Slovakia)
}

\author{
Abundancia dravcov a využívanie a preferencia biotopov myšiakom lesným Buteo buteo \\ a sokolom myšiarom Falco tinnunculus počas nehniezdnej sezóny v pol'nohospodárskej \\ krajine (západné Slovensko)
}

\section{Vladimír NEMČEK}

\begin{abstract}
Habitat use and preferences by raptors were studied during three non-breeding seasons (2011-2013) in an agricultural landscape in western Slovakia. The non-breeding season on agricultural land showed high variation and changes in the cover of habitats related to human activities. The most abundant raptor species were the common buzzard Buteo buteo (L.) (152 individuals) and the common kestrel Falco tinnunculus (L.) (78 individuals). The common buzzard preferred alfalfa and avoided ploughed fields. The common kestrel showed a high habitat preference for alfalfa, corn fields, stubbles and fallow. It also avoided ploughed fields and wheat.
\end{abstract}

\begin{abstract}
Abstrakt: Počas troch mimohniezdnych sezón (2011-2013) bolo skúmané využívanie a preferencia biotopov dravcami v pol'nohospodárskej krajine na západnom Slovensku. Mimohniezdna sezóna v pol’nohospodárskej krajine preukázala vysokú variáciu a zmeny v pokrytí biotopov vo vzt’ahu k l'udským činnostiam. Najpočetnejším druhom dravcov boli myšiak lesný Buteo buteo (L.) (152 jedincov) a sokol myšiar Falco tinnunculus (L.) (78 jedincov). Myšiak lesný preferoval biotopy s lucernou a vyhýbal sa zoraným poliam. Sokol myšiar preukázal vysokú biotopovú preferenciu pre lucernu, kukuricu, strniská a úhory. Tiež sa vyhýbal zoraným poliam a pšenici.
\end{abstract}

Key words: landscape, agricultural land

Vladimír Nemček, Raptor Protection of Slovakia, Kuklovská 5, SK-84104 Bratislava, nemcek@dravce.sk.

Acknowledgments: This study was supported by the international project Conservation of Raptors and Owls - Slovakia - Austria CORO-SKAT according to European Regional Development Fund within the Cross-Border Cooperation Programme Slovakia Austria 2007-2013. I would like to thank Raptor Protection of Slovakia for the opportunity to work on this project.

\section{Introduction}

During the non-breeding season raptors often have different habitat and environment requirements than they have during the breeding season. Limitations in this period are food resources and habitats where prey is available (MacArthur \& Pianka 1966, Newton 1998).

A number of studies were carried out during the winter months involving the counting of wintering raptors and recognizing their habitat use (Ševčík 1995, Wuczynski 2003, Nikolov et al. 2006, Schindler et al. 2012, Baltag et al. 2013). Habitats in agricultural land rapidly change during autumn and winter, because fields are ploughed and also cropped. The agricultural landscape is composed of important foraging habitats for raptors hunting in open areas.

The common buzzard is the most abundant bird of prey in the Western Palaearctic (Cramp \& Simmons
1980). It breeds on trees and cliffs (Sergio et al. 2002). This species inhabits a great variety of landscapes but mainly mosaics of woodland and agricultural areas (Bijlsma 1997). It is a typical perch-hunting predator. Its main prey consists of small mammals, lagomorphs, birds, reptiles and worms (Mebs 1964, Graham et al. 1995, Kenward et al. 2001, Sergio et al. 2002, Šotnár \& Obuch 2009). The population of the common buzzard in the non-breeding period is formed of birds wintering in Central Europe (Northern populations) and of the local non-migrating population (Cepák et al. 2008). During winter the species is strongly connected to open habitats (Danko et al. 2002).

The common kestrel is also a common species in Europe (Village 2010). It nests in trees, on buildings and close to pastures, grasslands, agricultural land and in built-up areas (O'Connor 1982, Aviles et al. 2001). The 
dominant prey of this species is composed of small mammals, insects and birds (Korpimäki 1985, Darolová 1989, Van Zyl 1994, Gil-Delgado et al. 1995, Valkama et al. 1995, Romanowski 1996, Piattella et al. 1999, Sándor 1999, Salvati 2002, Souttou et al. 2006, Noga \& Kečkéšová 2008).

The primary aim of the present study was to reconsider the relationships between raptors and agricultural habitats during the non-breeding season. I tested the hypothesis that raptors use habitats in the agricultural landscape in proportion to the habitat coverage.

\section{Material and methods}

\section{S t u d y a r e a}

The study was carried out in an open, agricultural area of the Podunajská pahorkatina Hills ( $17^{\circ} 31^{\prime} 00^{\prime \prime}$ E, $48^{\circ}$ $\left.16^{\prime} 26^{\prime \prime} \mathrm{N}\right)$. The area covers $18.7 \mathrm{~km}^{2}$, and the average altitude is between $125-140 \mathrm{~m}$. The major habitat is arable land with windbreaks (Table 1). Habitats change during the year in the area. The study area is a part of the special protection area (SPA) Ulanska mokrad (NATURA 2000), which protects raptor species, such as the saker falcon (Falco cherrug), the Montagu's harrier (Circus pygargus), the black kite (Milvus migrans) and the red-footed falcon (Falco vespertinus).

\section{$\mathrm{Hab}$ it a t s availability}

Habitat categories were recorded with a GPS unit (Garmin eTrex 10) and a camera during the counting of the number of raptors. For each counting habitats were recorded by making photo documentation from the counting points. These were translated into GIS layers. Eight habitat categories were classified in the monitoring area - alfalfa, corn, fallow, wheat, beet \& rape, sunflowers, ploughed fields and stubbles. Beet and rape were merged into a single category because of the very small area of beet. The highest habitat diversity was recorded in September (Shannon index $=1.57$ ). In autumn, the landscape was more diverse due to the higher cover of stubbles and fallow. The lowest values were recorded during the winter months. Winter habitats were predominantly formed of ploughed fields and wheat. The size of field parts ranged from 0.3 to 143.6 ha.

\section{D a t a colle ction}

The raptor counting was performed during the nonbreeding season from 2011 to 2013 (twice in November and December of 2011, four times in January, September, November and December of 2012 and once in March of 2013). The field work was carried out between September and March. Each counting started at 10 a. m. and only when the weather conditions were with no snow cover, fog, rainfall or strong wind (over $10 \mathrm{~m} / \mathrm{s}$ ). The visibility was often low in the early mornings because of the fog. It often lasted until 10 a. m. The temperature did not fall below $0^{\circ} \mathrm{C}$. The field method used was the point transect (Gibbons and Gregory 2006). A total of 7 counting points were established. Points were located 700-1300 m apart and with the good view of the area. A binocular $(10 \times 42)$ was used to search for raptors and a monocular $(30 \times 65)$ for identifying raptors. Raptors were recorded within two kilometres. The habitat category was added only when I was sure where the raptor was hunting. The average distance between the counting points was $800 \mathrm{~m}$. Each point was sampled for 20 minutes. Only hunting birds of prey were selected for the study. I identified hunting birds as birds perched on trees or on the ground, hunting with

Tab. 1. The cover of the habitats in the study area [\%]. A - average, $H^{\prime}-$ Shannon diversity index.

Tab. 1. Pokryvnost' biotopov v skúmanej oblasti [\%]. A - priemer, $\mathrm{H}^{\prime}-$ Shannonov index diverzity.

\begin{tabular}{|c|c|c|c|c|c|c|c|c|}
\hline \multicolumn{3}{|c|}{2011} & \multicolumn{4}{|c|}{2012} & \multicolumn{2}{|l|}{2013} \\
\hline habitat type & $\mathbf{X I}$ & XII & $\mathrm{I}$ & IX & $\mathbf{X I}$ & XII & III & $A$ \\
\hline alfalfa & 4.2 & 3.2 & 3.2 & 6.6 & 8.8 & 8.8 & 8.8 & 6.2 \\
\hline corn & 0.0 & 0.0 & 0.0 & 12.0 & 0.0 & 0.0 & 0.0 & 1.7 \\
\hline rape and beet & 9.8 & 7.4 & 7.4 & 0.0 & 3.36 & 3.4 & 3.4 & 5.0 \\
\hline wheat & 42.9 & 42.9 & 42.9 & 0.0 & 35.2 & 35.1 & 35.1 & 33.4 \\
\hline ploughed field & 22.3 & 43.6 & 46.2 & 41.2 & 51.6 & 51.6 & 51.6 & 44.0 \\
\hline stubbles & 20.1 & 2.6 & 0.0 & 19.0 & 0.8 & 0.8 & 0.8 & 6.3 \\
\hline fallow & 0.4 & 0.0 & 0.0 & 14.3 & 0.0 & 0.0 & 0.0 & 2.1 \\
\hline sunflower & 0.0 & 0.0 & 0.0 & 6.6 & 0.0 & 0.0 & 0.0 & 0.9 \\
\hline $\mathbf{H}^{\prime}$ & 1.41 & 1.12 & 1.02 & 1.57 & 1.08 & 1.08 & 1.08 & \\
\hline
\end{tabular}


a hovering flight or circling, gliding with a prey attack. Other types of flight (circling, gliding, direct flight without an attack) were not considered as hunting. I assigned a category to the habitat where each individual raptor was hunting. In the case of a flying raptor, I assigned the category of the habitat over which it was flying. All individual birds were recorded only once when they were observed for the first time. Birds perched on trees between two habitats were assigned to the habitat being monitored by the raptor.

\section{D a t a a n a y s is}

The monitoring area and size of the habitats were calculated using the Quantum GIS program (version 1.8.0.) (QGIS Development Team 2013). The LibreOffice program (The Document Foundation 2013) was used for the data. Tables with the recorded birds, types of habitats and graphs were created in this software. The type of habitat was identified and recorded using the Geographic Information System (GIS) from photos taken during the counting. The statistical analysis was performed in Instat+ v. 3.37 (Statistical Services Centre 2012). Habitat preferences were tested with the Chisquare test for goodness-of-fit with $\alpha=0.01$. The $\alpha$ level was corrected with Bonferroni correction for two tests $(\alpha=0.01 / 2$ tests). In each habitat I expected numbers of birds according to the ratio of habitat cover in the area. The sum of expected birds was the sum of recorded birds during the counting. I counted birds which were recorded in each habitat category and compared them with the numbers of expected birds in each habitat. The Chi-square test method was used for the

Tab. 2. Abundance of raptors in the study area. $\mathrm{NI}$ - numbers of individuals in the area for all counts, NIA - average number of individuals/count, DIA - average density of individuals $/ 10 \mathrm{~km}^{2}$.

Tab. 2. Abundancia dravcov v skúmanej oblasti. NI - celkový počet jedincov zaznamenaných $\mathrm{v}$ oblasti, NIA - priemerný počet jedincov/sčítanie, DIA - priemerná hustota jedincov/10 $\mathrm{km}^{2}$.

\begin{tabular}{lcrr}
\hline species & NI & NIA & DIA \\
\hline Aquila heliaca & 8 & 1.1 & 0.6 \\
Buteo buteo & 152 & 21.7 & 11.6 \\
Buteo lagopus & 9 & 1.3 & 0.7 \\
Buteo rufinus & 1 & 0.1 & 0.1 \\
Circus aeruginosus & 6 & 0.9 & 0.5 \\
Circus cyaneus & 14 & 2.0 & 1.1 \\
Falco tinnunculus & 78 & 11.1 & 6.0 \\
Falco vespertinus & 1 & 0.1 & 0.1 \\
\hline$\sum$ & $\mathbf{2 6 9}$ & & \\
\hline
\end{tabular}

habitat preference of the common buzzard and of the common kestrel. These species were the most common raptors in this area. Data were analysed independently for each species because of the slightly different habitat requirements of each species (Butet et al. 2010). Habitat diversity was calculated with the Shannon Diversity Index.

\section{Results}

A bundance of hunting $\mathrm{r}$ a p t o r s

A total of 269 observations of 8 raptor species were made during three non-breeding seasons (2011-2013). Habitat preference was not tested for all raptors species because of a lack of data. The total abundance of hunting raptors showed the highest number of the common

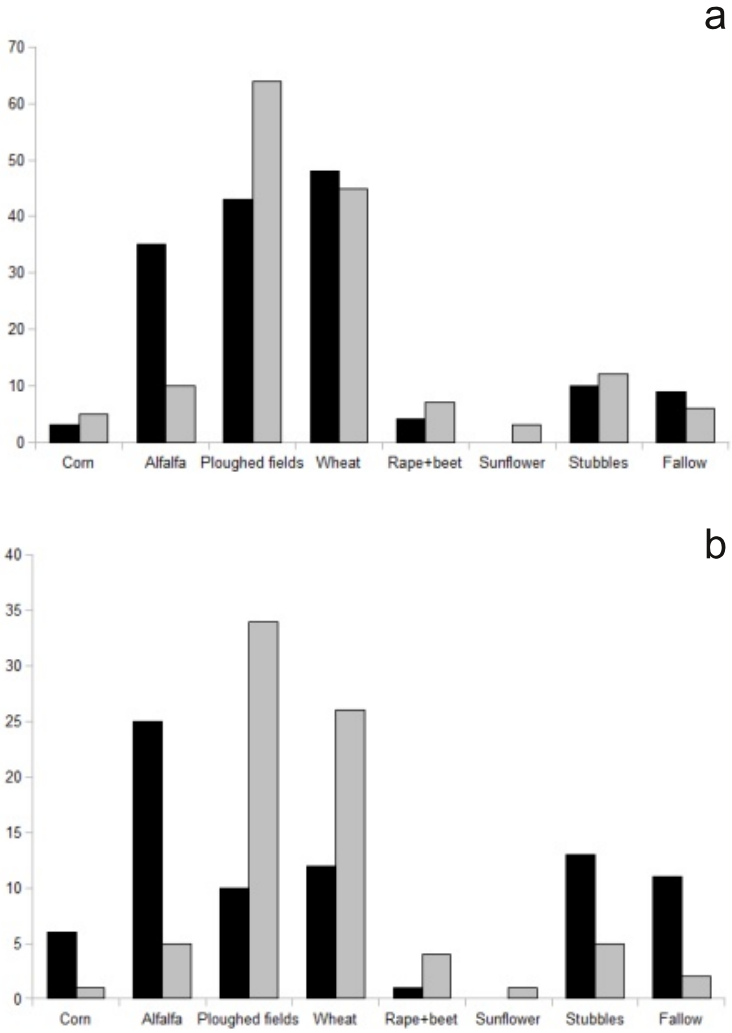

Fig. 1. Hunting habitat preference of (a) the common buzzard (Buteo buteo) and (b) the common kestrel (Falco tinnunculus). Number of recorded (black columns) and expected (grey columns) individuals on the habitat types are presented.

Obr. 1. Preferencia biotopov (a) myšiakom lesným (Buteo buteo) a (b) sokolom myšiarom (Falco tinnunculus). Zobrazené sú počty zaznamenaných (čierne stĺpce) a odhadovaných (sivé stlpce) jedincov $v$ typoch biotopov. 
buzzard (Table 2). The population of this species was stable, with the highest number occurring in September (41 individual birds). The common kestrel was the second most common species, and the highest number of this species (49 individual birds) was also recorded in September. During the rest of winter, the population of this species was stable, but low in number. Other raptors were relatively rare.

\section{$\mathrm{Hab}$ i t a t prefere n c e}

Habitat preference was significant for the common buzzard $(\chi 2=76.5, \mathrm{DF}=7, \mathrm{p}<0.005)$ : it preferred the alfalfa habitat (Fig. 1a). A lower number of this species was recorded in ploughed fields. Other categories had similar recorded and expected numbers. The common kestrel was recorded with a high habitat preference for alfalfa, corn fields, stubbles and fallow land $(\chi 2=186, \mathrm{DF}=7, \mathrm{p}<0.005)$ (Fig. 1b). A large difference between recorded and expected numbers of this species was also observed in ploughed fields and wheat. All categories showed some degree of positive or negative preferences. The common kestrel used more alfalfa and fallow habitats and fewer wheat and ploughed fields in comparison with the common buzzard.

\section{Discussion}

\section{A b u n d a n c e}

Results showed a high abundance of the common buzzard and the common kestrel in comparison with other raptor species. These two species have been recorded as the most abundant birds of prey in many studies in Europe (Ševčík 1995, Mülner 2000, Boano $\&$ Toffoli 2002). The abundance during winter was similar to results in the Czech Republic and Poland. The common buzzard was more abundant in November, and its population was relative stable until January. Then the population slowly decreased (Ševčík 2005, Wuczynski 2003). The present study contained a small sample size (7 counts) and started in September, when the abundance of the common buzzard and common kestrel was at its highest.

\section{Habitat us e and preference}

Many holes and paths of rodents were observed in the alfalfa. I assumed that alfalfa fields attract the common buzzard and the common kestrel because of their stable environment. This did not change during autumn and winter. Habitat selection by predators of small mammals is in relation to the density of these species and to the height of the vegetation. Raptors prefer lower vegetation height because of the easier search for prey (Sheffield et al. 2001, Aschwanden et al. 2005). A study in western France specifically identified negative associations between the lower abundance of two raptor species (the common buzzard and the common kestrel) and agricultural intensification in a plot with the highest cover of crop areas (Butet et al. 2010). These species have slightly different requirements for the landscape. The common kestrel is able to nest in more fragmented landscapes and is better adapted to exploit less abundant but more widespread small mammal prey species within a cultivated matrix (Butet et al. 2010).

\section{C o m m o n b u z z a r d}

Alfalfa covered a small area, but the number of birds was higher than expected. Results showed a high preference for this kind of habitat. A negative preference was recorded in ploughed fields. Overall, the species distribution in the non-breeding season is strongly affected by food availability (Newton 1998). The common buzzard preferred a habitat with a rich dietary base (alfalfa) (Heroldová et al. 2007). The use of wheat and ploughed fields by this species could be because of searching for carcasses and worms in these habitats. This is probably reflected in the easy foraging for invertebrates in freshly ploughed fields (Dare 1957).

Results did not show any preference for stubbles, as was stated in the article from Poland (Wuczynski 2005). In Poland, permanent papilionaceous crops, along with cereal stubbles, margin habitats, meadows and maize stubbles were preferentially used, whereas bare tillage (ploughed fields) and winter cereals were avoided (Wuczynski 2005). In south-western Poland the common buzzard most often used cereal stubbles (Orlowski 2006). During winter, stubbles were ploughed in the study area, and only a small part of them remained. In the area with a high proportion of grassland (48.6\%), the common buzzard especially used the grassland (more than 75\%) and very few birds used fallow (lower than 2\%) (Mülner 2000). I can consider that the common buzzard uses available habitats during the non-breeding season but prefers habitats with abundant small mammals.

\section{C o m m o n k e s t r e 1}

The habitat preference of the common kestrel was different. The abundance of this species was not proportional to habitats in the area. It preferred habitats with a smaller area but a higher diversity and an abundance of small mammals (fallow, alfalfa and stubbles) (Heroldová et al. 
2007). Ploughed fields and wheat were less important for this species. The numbers of recorded birds were lower than the expected numbers. These habitats were also used, but less than I assumed. Different habitat use was recorded in Poland (Orlowski 2006). In the study from Wroclaw, the common kestrel used habitats proportional to their availability. More than $50 \%$ of the study area was formed of old fallow fields, which were used intensively (Orlowski 2006). A preference for grassland was found in Italy (Casagrande et al. 2008), and high usage of grassland was also recorded in Austria (Mülner 2000). The small mammal density was not the highest in grassland, but prey was the most available there. Shrubb (1980) found results similar to those of the present study. The common kestrel especially used the clover ley and grassland. Stubbles and cereals were also more used during the non-breeding season. However, cereals covered most of the checked area.

\section{Conclusion}

The results of the present study showed a high abundance of the common buzzard and the common kestrel in agricultural land during the non-breeding season. They indicated a raptor preference for certain habitat categories. Different habitat use and preferences were recorded between the species. The alfalfa habitat was preferred by both species.

\section{References}

Aschwanden J, Birrer S \& Jenni L 2005: Are ecological compensation areas attractive hunting sites for common kestrels (Falco tinnunculus) and long-eared owls (Asio otus)? Journal of Ornithology 146: 279-286. DOI: 10.1007/s10336-005-0090-9.

Aviles JM, Sanchez JM \& Parejo D 2001: Breeding rates of Eurasian kestrels (Falco tinnunculus) in relation to surrounding habitat in southwest Spain. Journal of Raptor Research 35: 31-34.

Baltag E, Pocora V, Sfîcã L \& Bolboacã LE 2013: Brief report common buzzard (Buteo buteo) population during winter season in North-Eastern Romania: the influences of density, habitat selection, and weather. Ornis Fennica 90: 1-7.

Bijlsma RG 1997: Buteo buteo - Buzzard, 160-161. In: Hagemeijer WJM \& Blair MJ (eds): The EBCC Atlas of European breeding birds. T\&AD Poyser, London, 904.

Boano G \& Toffoli R 2002: A line transect survey of wintering raptors in the western PO Plain of northern Italy. Journal of Raptor Research 36: 128-135.
Butet A, Michel N, Rantier Y, Comor V, Hubert-Moy L, Nabucet J \& Delettre Y 2010: Responses of common buzzard (Buteo buteo) and Eurasian kestrel (Falco tinnunculus) to land use changes in agricultural landscapes of Western France. Agriculture, ecosystems \& environment 138: 152-159.

Casagrande S, Nieder L, Di Minin E, La Fata I \& Csermely D 2008: Habitat utilization and prey selection of the common kestrel Falco tinnunculus in relation to small mammal abundance. Italian Journal of Zoology 75: 401-409. DOI: 10.1080/11250000802085526.

Cepák J, Klvaňa P, Škopek J, Schröpfer L, Jelínek M, Hořák D, Formánek J \& Zárybnický J 2008: Czech and Slovak bird migration atlas. Aventinum. Praha. $608 \mathrm{pp}$.

Cramp S \& Simmons KEL 1980: Handbook of the birds of Europe, the Middle East and North Africa. Vol. 2. Hawks to bustards. Oxford University Press, London, 696.

Danko Š, Darolová A \& Krištín A 2002: Rozšírenie vtákov na Slovensku [Distribution of birds in Slovakia]. Veda, Bratislava, 688. [In Slovak with English summaries]

Darolová A 1989: Potrava sokola myšiara (Falco tinnunculus L., 1758) v podmienkach mestskej aglomerácie Bratislavy [Diet of common kestrel (Falco tinnunculus L., 1758) in the conditions of Bratislava urban agglomeration]. Biológia 44: 575-584. [In Slovak with abstract in English].

Gil-Delgado JA, Verdejo J \& Barba E 1995: Nestling diet and fledgling production of Eurasian kestrels (Falco tinnunculus) in eastern Spain. Journal of Raptor Research 29: 240-244.

Gibbons WD \& Gregory RD 2006: Birds in: Sutherland JW (eds) Ecological Census Techniques a handbook. Cambridge University Press. New York. 324-326.

Graham IM, Redpath SM \& Thirgood SJ 1995: The diet and breeding density of common buzzards Buteo buteo in relation to indexes of prey abundance. Bird Study 42: 165-173.

Heroldová M, Bryja J, Zejda J \& Tkadlec E 2007: Structure and diversity of small mammal communities in agriculture landscape. Agriculture, Ecosystems \& Environment. 120(2-4): 206-210.

Kenward RE, Walls SS \& Hodder KH 2001: Life path analysis: scaling indicates priming effects of social and habitat factors on dispersal distances. Journal of Animal Ecology 70: 1-13. 
Korpimäki E 1985: Diet of the common kestrel Falco tinnunculus in the breeding season. Ornis Fennica 62: 130-137.

MacArthur RH \& Pianka ER 1966: On optimal use of a patchy environment. American Naturalist 100: 603-609.

Mebs T 1964: Zur Biologie und Populationsdynamik des Mäusebussards (Buteo buteo) (Unter besonderer Berlicksichtigung der Abhängigkeif vom Massenwechsel der Feldmaus Microtus arvalis). Journal für Ornithologie 105: 247-306.

Mülner B 2000: Population numbers, habitat preferences and perch use of wintering common buzzards (Buteo buteo) and common kestrels (Falco tinnunculus) in the upper Mur river valley (Styria). Egretta 43: 20-36.

Newton I 1998: Population limitation in birds. Academic Press, San Diego, California, USA, 597.

Nikolov S, Spasov S \& Kambourova N 2006: Density, number and habitat use of common buzzard (Buteo buteo) wintering in the lowlands of Bulgaria. Buteo 15: 39-47.

Noga M \& Kečkéšová L 2008: The diet of the common kestrel in the urban environment of the city of Nitra. Slovak Raptor Journal 2: 81-85. DOI: 10.2478/v10262-012-0021-7

O'Connor JR 1982: Habitat occupancy and regulation of clutch size in the European kestrel Falco tinnunculus. Bird Study 29(1): 17-26. DOI: 10.1080/00063658209476734

Orlowski G 2006: Cropland use by birds wintering in arable landscape in south-western Poland. Agriculture, Ecosystems and Environment 116: 273-279. DOI: $10.1016 /$ j.agee.2006.03.005

QGIS Development Team 2013: QGIS Geographic Information System. Open Source Geospatial Foundation Project. http://qgis.osgeo.org.

Piattella E, Salvati L, Manganaro A \& Fattorini S 1999: Spatial and temporal variations in the diet of the common kestrel (Falco tinnunculus) in urban Rome, Italy. Journal of Raptor Research 33: 172-175.

Romanowski J 1996: On the diet of urban kestrels (Falco tinnunculus) in Warsaw. Buteo 8: 123-130.

Salvati L 2002: Spring weather and breeding success of the Eurasian kestrel (Falco tinnunculus) in urban Rome, Italy. Journal of Raptor Research 36: $81-84$.

Sándor AD 1999: Diet shift and niche overlap of coexisting barn owl (Tyto alba) and Eurasian kestrel (Falco tinnunculus) in non-breeding period. Buteo (Supplement): 62.
Sergio F, Boto A, Scandolara C \& Bogliani G 2002: Density, nest sites, diet, and productivity of common buzzards (Buteo buteo) in the Italian pre-Alps. Journal of Raptor Research 36: 24-32.

Sheffield L, Crait J, Edge W \& Wang G 2001: Response of American kestrels and gray-tailed voles to vegetation height and supplemental perches. Canadian Journal of Zoology 79: 380-385.

Shrubb M 1980: Farming influences on the food and hunting of kestrels. Bird Study 27 (2): 109-115.

Schindler S, Hohmann U, Probst R, Nemeschkal HL \& Spitzer G 2012: Territoriality and habitat use of common buzzards (Buteo buteo) during late autumn in northern Germany. Journal of Raptor Research 46: 149-157.

Souttou K, Baziz B, Doumandji S, Denys C \& Brahimi R 2006: Analysis of pellets from a suburban common kestrel Falco tinnunculus nest in El Harrach, Algiers, Algeria. Ostrich 77: 175-178.

Statistical Services Centre 2005-2012: Instat+ 3.37. University of Reading. United Kingdom. www.reading.ac.uk/ssc $/ \mathrm{n} / \mathrm{n}$ instat.htm

Ševčík J 1995: Abundance of wintering birds of prey in an agricultural landscape of the Trebon Region. Buteo 7: 82-84.

Šotnár K \& Obuch J 2009: Feeding ecology of a nesting population of the common buzzard (Buteo buteo) in the Upper Nitra Region, Central Slovakia. Slovak Raptor Journal 3: 13-20. DOI: 10.2478/v10262-012-0028-0

The Document Foundation 2013: LibreOffice 4.0.6.2. https://www.libreoffice.org/download

Valkama J, Korpimäki E \& Tolonen P 1995: Habitat utilization, diet and reproductive success in the kestrel in a temporally and spatially heterogeneous environment. Ornis Fennica 72: 49-61.

van Zyl AJ 1994: A comparison of the diet of the common kestrel Falco tinnunculus in South Africa and Europe. Bird Study 41(2): 127-130. DOI: 10.1080/00063659409477208.

Village A 2010: The kestrel. T\&AD Poyser, London, 352.

Weir D \& Picozzi N 1975: Aspects of social behaviour in the buzzard. British Birds 68: 125-141.

Wuczynski A 2003: Abundance of common buzzard (Buteo buteo) in the Central European wintering ground in relation to the weather conditions and food supply. Buteo 13: 11-20.

Wuczynski A 2005: Habitat use and hunting behaviour of common buzzards Buteo buteo wintering in south-western Poland. Acta Ornithologica 40: 147-154. DOI: 10.3161/068.040.0210. 